\title{
CRYSTAL STRUCTURE, SPECTRAL CHARACTERIZATION, MOLECULAR MODELING STUDIES AND STRUCTURAL EFFECTS OF THE PROTON TRANSFER PROCESS FOR (E)-5-METHOXY-2-[(3,4-DIMETHYLPHENYLIMINO) METHYL]PHENOL
}

\author{
Basak Kosar Kırca ${ }^{1}$, Gonca Özdemir Tarı ${ }^{2 *}$, Çiğdem Albayrak Kaştaş ${ }^{3}$, Mustafa Odabaşoğlu ${ }^{4}$, \\ Orhan Büyükgüngör ${ }^{5}$ \\ ${ }^{1}$ Department of Science Education, Sinop University, Sinop, Turkey \\ ${ }^{2}$ Vezirköprü Vocational School, Ondokuz Mayls University, Samsun, Turkey \\ ${ }^{3}$ Department of Chemistry, Sinop University, Sinop, Turkey \\ ${ }^{4}$ Chemical Technology Program, Pamukkale University, Denizli, Turkey \\ ${ }^{5}$ Department of Physics, Ondokuz Mayis University, Samsun, Turkey
}

gozdemir@omu.edu.tr

The main purpose of this study is to characterize a new organic material, (E)-5-methoxy-2-[(3,4dimethylphenylimino)methyl]phenol, which was synthesized and grown as a single crystal. The molecular structure and spectroscopic properties of the ortho-hydroxy Schiff base compound were determined by X-ray diffraction analysis, Fourier-transform infrared (FT-IR), ultraviolet-visible (UV-Vis) and nuclear magnetic resonance (NMR) spectroscopy techniques, experimentally and computationally with density functional theory (DFT) calculations. X-ray and UV-Vis studies show that the compound exists in an $\mathrm{OH}$ tautomeric form in the solid and solvent media. The gas phase geometry optimizations of two possible forms of the title compound, resulting from the prototropic tautomerism, were obtained using DFT calculations at the B3LYP/6-311G+(d,p) level of theory. A relaxed potential energy surface (PES) scan was performed based on the optimized geometry of the $\mathrm{OH}$ tautomeric form by varying the redundant internal coordinate, the O-H bond distance. According to the PES scan process, the molecular geometry is strongly affected by the intramolecular proton transfer. The calculated first hyperpolarizability indicates that the compound could be a good material for non-linear optical applications.

Keywords: Schiff base; prototropic tautomerism; intramolecular proton transfer; NLO; DFT

\section{КРИСТАЛНА СТРУКТУРА, СПЕКТРАЛНА КАРАКТЕРИЗАЦИЈА, СТУДИИ ЗА МОЛЕКУСКО МОДЕЛИРАњЕ И СТРУКТУРНИ ЕФЕКТИ ОД ПРОЦЕСОТ НА ПРОТОН ТРАНСФЕР ЗА $(E)$-5- МЕТОКСИ-2-[(3,4-ДИМЕТИЛФЕНИЛИМИНО)МЕТИЛ]ФЕНОЛ}

Главна цел на ова истражување е да се карактеризира нов органски материјал, $(E)-5$-метокси-2-[(3,4диметилфенилимино)метил]фенол, што беше синтетизиран и израснат како монокристал. Молекулската структура и спекторскопските својства на орйо-хидрокси Шифовата база беа определени експериментално со помош на рендгенска дифракциска анализа, Фуриеова трансформна инфрацрвена спектроскопија (FTIR), ултравиолетова спектроскопија (UV-Vis) и нуклеарно-магнетна спектроскопска анализа и пресметковно со помош на теоријата на густината на функционалот (DFT). Испитувањата со рендгенската дифракција и UV-Vis покажуваат дека соединението постои во ОН тавтомерна форма во цврста состојба и во раствор. Геометриската оптимизација во гасна фаза на двете можни форми на наведеното соединение кои се резултат на прототропен тавтомеризам беа добиени со пресметки според DFT на нивото на теоријата B3LYP/6-311G+(d,p). Скенирањето на површината на релаксираната потенцијална енергија (PES) беше изведено врз оптимизираната геометрија на $\mathrm{OH}$ тавтомерната форма со менување на редундантната внатрешна координата, должината на О-H врската. Според скенот на процесот на PES, молекулската геометрија е под силно влијание на интрамолекулскиот 
трансфер на протони. Пресметаната прва хиперполаризабилност укажува дека соединението би било добар материјал за нелинеарни оптички апликации.

Клучни зборови: Шифови бази; прототропна тавтомерија; меѓумолекулски трансфер на протони; NLO; DFT

\section{INTRODUCTION}

The reaction of an aldehyde and a primary amine forms a Schiff base compound with a $\mathrm{C}=\mathrm{N}$ double bond. Schiff bases have a wide range of applications in the fields of coordination chemistry, biochemistry, pharmacy, nanotechnology, optical devices and textiles [1-18]. In particular, the ortho-hydroxy class of Schiff bases has been attractive for physicists and chemists for many years because of its interesting photochromic and thermochromic features in the solid state. These photochromic and thermochromic features are caused by an intramolecular proton transfer from the hydrox$\mathrm{yl} \mathrm{O}$ atom to the imine $\mathrm{N}$ atom with a change in the $\pi$-electronic system. The change in the $\pi$-electronic system accompanies the proton transfer and the planarity of molecule is affected by the transfer
[19]. As the names suggest, transfer occurs under the influence of light in photochromic compounds and under the influence of temperature in thermochromic compounds. These interesting properties were discovered by Senier and Shepherd in 1909 and are still being studied today [20, 21]. orthohydroxy Schiff base compounds adopt $\mathrm{OH}$ (enolimine/benzenoid) [22, 23] or $\mathrm{NH}$ (keto-amine/ quinoid) $[24,25]$ tautomeric forms in the solid state with reference to the location of the transferred proton. X-ray diffraction distinguishes these two tautomeric forms easily. The $\mathrm{NH}$ form can also be zwitterionic, with the scarcely observed zwitterionic form differing from the $\mathrm{NH}$ form on the basis of the $\mathrm{N}^{+}-\mathrm{H}$ bond distance and aromaticities of the rings [26-28]. Figure 1 shows the tautomeric forms and observed strong intramolecular hydrogen bonds depending on the forms.

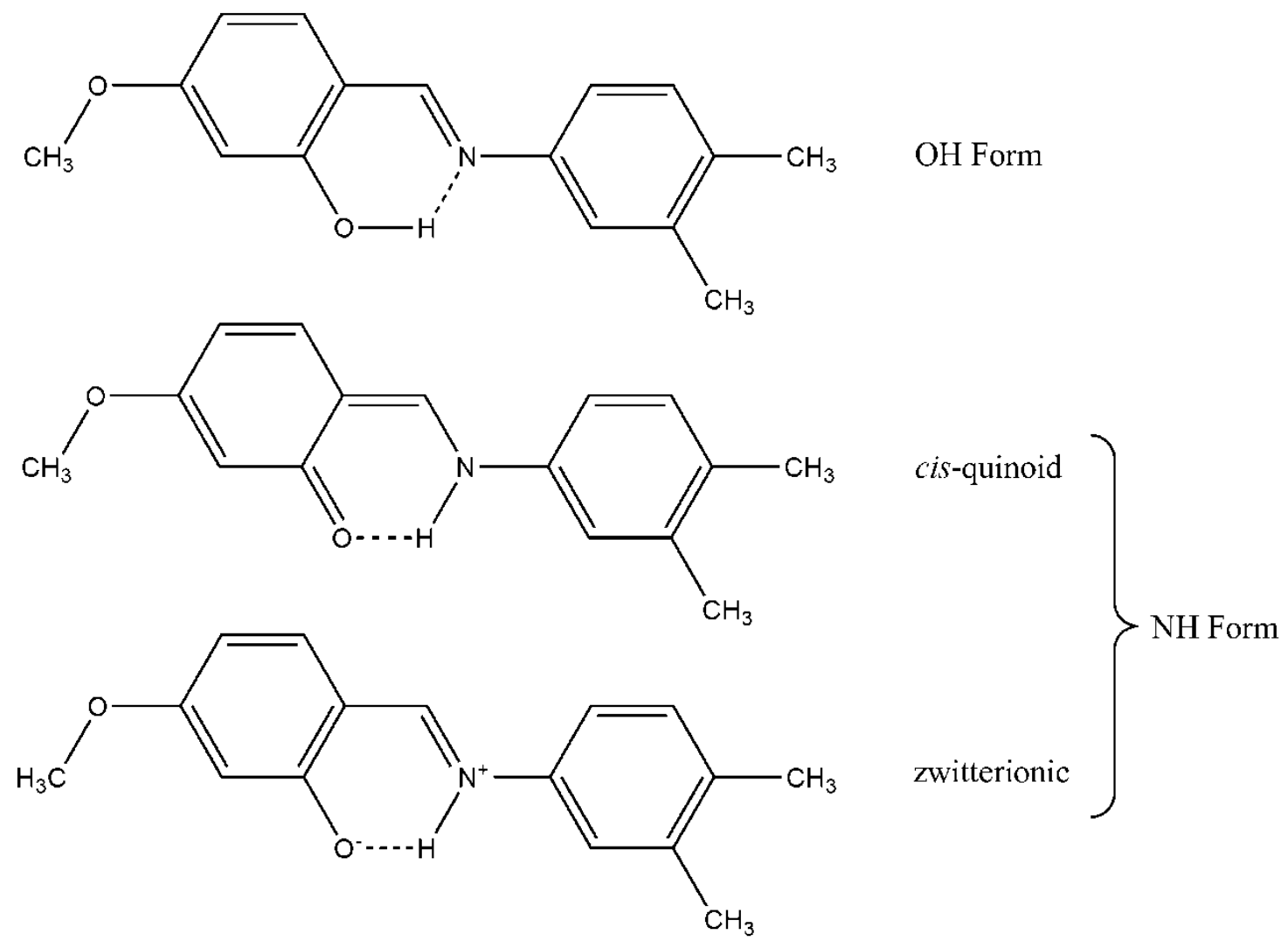

Fig. 1. Possible tautomeric forms of the title compound 
In this study, we present the synthesis and crystallographic, spectroscopic and quantum chemical computational studies of an ortho-hydroxy Schiff base compound, (E)-5-methoxy-2-[(3,4dimethylphenylimino)methyl]phenol.

\section{EXPERIMENTAL AND COMPUTATIONAL PROCEDURES}

\subsection{Synthesis of title compound}

The title compound was prepared by refluxing a mixture of a solution containing 2-hydroxy4-methoxybenzaldehyde $(0.5 \mathrm{~g}, 3.3 \mathrm{mmol})$ in 20 $\mathrm{ml}$ of ethanol and a solution containing 3,4dimethylaniline $(0.4 \mathrm{~g}, 3.3 \mathrm{mmol})$ in $20 \mathrm{ml}$ of ethanol. The reaction mixture was stirred for $1 \mathrm{~h}$ under reflux. The crystals suitable for X-ray analysis were obtained from ethanol by slow evaporation (yield 85\%, m.p 359-360 K).

\subsection{Instrumentation}

The melting point was determined by an electro-thermal melting point apparatus. The FT-IR spectrum of the title compound was recorded on a Bruker 2000 spectrometer in a $\mathrm{KBr}$ disk. Absorption spectra were recorded on a Unicam UV-Vis spectrometer using a $1 \mathrm{~cm}$ path length of the quartz cell. The ${ }^{1} \mathrm{H}-\mathrm{NMR}$ spectrum was recorded on Bruker Ultrashield $300 \mathrm{MHz}$ spectrometer. All diffraction measurements were performed at room temperature (296 K) using graphite monochromated MoK $\alpha$ radiation $(\lambda=0.71073 \AA)$ with a Stoe IPDS 2 diffractometer.

\subsection{Crystal structure determination}

A suitable sample of size $0.68 \times 0.43 \times 0.28$ $\mathrm{mm}^{3}$ was chosen for the single crystal X-ray study. Reflections were collected in the rotation mode $(\omega$ scanning mode) and cell parameters were determined using X-AREA software [29]. The absorption correction $\left(\mu=0.08 \mathrm{~mm}^{-1}\right)$ was achieved by the integration method via X-RED32 software [29]. The structure was solved by direct methods using SHELXS-97 [30]. The refinement was carried out by a full-matrix least-squares method using SHELXL-97 on the positional and anisotropic temperature parameters of the non-hydrogen atoms, or equivalently, corresponding to 176 crystallographic parameters [30]. All non-hydrogen atom parameters were refined anisotropically and $\mathrm{H}$ atoms, except for $\mathrm{H} 1$, were positioned geometrically and refined using a riding model. The $\mathrm{C}-\mathrm{H}$ bond distances were fixed to $0.93 \AA$ for $\mathrm{CH}$ and $0.96 \AA$ for $\mathrm{CH}_{3}$ groups. The $\mathrm{U}_{\text {iso }}$ values of $\mathrm{H}$ atoms were also fixed to 1.2 times the $\mathrm{U}_{\mathrm{eq}}$ value of the parent atoms for $\mathrm{CH}$ and 1.5 times the $\mathrm{U}_{\mathrm{eq}}$ value of the parent atoms for $\mathrm{CH}_{3}$ groups. Under the condition of a I $>2 \sigma(\mathrm{I})$ threshold, the structure was refined to $\mathrm{R}_{\text {int }}=0.058$ with 2071 observed reflections. Other data collection conditions and parameters of the refinement process are listed in Table 1.

Table 1

Crystal data and refinement parameters of the title compound

\begin{tabular}{|c|c|}
\hline Formula & $\mathrm{C}_{16} \mathrm{H}_{17} \mathrm{NO}_{2}$ \\
\hline Formula weight & 255.31 \\
\hline Crystal color & Yellow \\
\hline Crystal system & Monoclinic \\
\hline Space group & $P 2_{1} / \mathrm{c}$ \\
\hline $\mathrm{Z}$ & 4 \\
\hline$a, b, c$ & 13.6589 (8), 6.0320 (3), 20.1848 (11) \\
\hline$\alpha, \beta, \gamma$ & $90,124.606(4), 90^{\circ}$ \\
\hline $\mathrm{V}$ & $1368.79(13) \AA^{3}$ \\
\hline Radiation type & Mo $\mathrm{K} \alpha$ \\
\hline$\mu$ & $0.08 \mathrm{~mm}^{-1}$ \\
\hline $\mathrm{T}_{\max }, \mathrm{T}_{\min }$ & $0.958,0.981$ \\
\hline Measured reflections & 16076 \\
\hline Independent reflections & 2832 \\
\hline Reflections with $I>2 \sigma(I)$ & 2071 \\
\hline Number of parameters & 176 \\
\hline$\theta_{\max }, \theta_{\min }$ & $27.56^{\circ}, 1.50^{\circ}$ \\
\hline Scan range & $-17<\mathrm{h}<17,-7<\mathrm{k}<7,-26<1<26$ \\
\hline$R\left[F^{2}>2 \sigma\left(F^{2}\right)\right]$ & 0.0464 \\
\hline$w R\left(F^{2}\right)$ & 0.1225 \\
\hline $\mathrm{S}$ & 1.051 \\
\hline$\Delta \rho_{\max }, \Delta \rho_{\min }$ & $0.17,-0.14{\mathrm{e} \AA^{-3}}^{-1}$ \\
\hline
\end{tabular}




\subsection{Supplementary data}

CCDC 942104 contains the supplementary crystallographic data for this study. These data can be obtained free of charge via www.ccdc.cam.ac. uk/data_request/cif by emailing data_request@ ccdc.cam.ac.uk, or by contacting The Cambridge Crystallographic Data Centre, 12, Union Road, Cambridge CB2 1EZ, UK; fax: +44 1223336033.

\subsection{Computational details}

The analytical gradient methods of DFT with Becke's three parameter (B3) exchange functional together with the Lee-Yang-Parr (LYP) non-local correlation functional, symbolized B3LYP [31, 32] were performed to reach the energy minima in the optimization processes of two tautomers by means of the $6-311+\mathrm{G}(\mathrm{d}, \mathrm{p})$ basis set implemented in the Gaussian 03W software package [33].

The crystallographically obtained coordinates were used to start the geometry optimization calculations in the gas phase and no imaginary frequency modes were obtained at the optimized geometries for the tautomers, so there are true minima on the potential energy surfaces were found for both. We also performed the optimizations in benzene $(\varepsilon=2.3)$, ethanol $(\varepsilon=24.5)$ and DMSO $(\varepsilon=$ 46.7) using the polarizable continuum model (PCM) [34] to investigate the energetic behaviors and changes in the geometric parameters of the molecule in various environments. The PCM model can give good approximations regarding the solvent effects on the molecule if there is no specific interaction, such as hydrogen bond formation between the solute and solvent $[35,36]$.

In the potential energy surface (PES) scan process, the $\mathrm{O} 1-\mathrm{H} 1$ bond distance was taken as a redundant coordinate and varied from 0.997 to $1.697 \AA$ with 16 steps of $0.05 \AA$. All the remaining internal coordinates were fully optimized. On this basis, we described the potential energy barrier belonging to the intramolecular proton transfer and observed the effects of transfer on the molecular geometry with the change in the $\pi$-electronic system.

The vibrational frequencies were calculated at the same level of theory and the obtained frequencies were scaled by 0.9688 depending on the method and basis set used [37]. The absorption spectra of the tautomers were calculated using time-dependent density functional theory (TDDFT) started from the solution phase optimized geometries. The linear polarizability and the total static first hyperpolarizability were obtained by the molecular polarizabilities in order to show the non- linear optical (NLO) activity of the molecule. The standard thermodynamic functions and their components were computed at constant pressure (by changing the temperature) and temperature (by changing the pressure) in the gas phase.

\section{RESULTS AND DISCUSSION}

\subsection{Crystal structure}

Figure 2 shows an ORTEP-3 [38] plot with an atom numbering scheme for the title compound. Hydrogens are drawn as small spheres of arbitrary radii and the other atoms are seen as displacement ellipsoids at a $30 \%$ probability level.

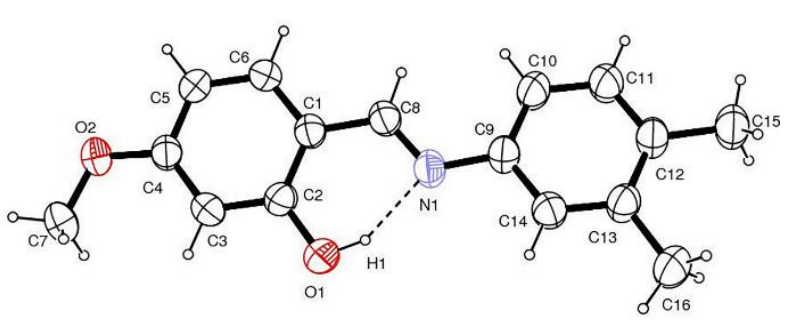

Fig. 2. Atom numbering scheme of the title compound. The dotted line indicates the intramolecular hydrogen bond.

As seen in Figure 2, the compound adopts an E configuration about the $\mathrm{C}=\mathrm{N}$ double bond and has two six-membered rings, $\mathrm{C} 1 / \mathrm{C} 6$ and $\mathrm{C} 9 / \mathrm{C} 14$. The dihedral angle between the rings is $6.87^{\circ}$, which makes the molecular geometry almost planar. The literature proposes that the molecules showing thermochromism are planar and the photochromic molecules are non-planar [15, 39]. According to the planarity of the molecule, the proton transfer occurs under the influence of temperature in the title compound.

Selected geometrical parameters are listed in Table 2. The lengths of the $\mathrm{N} 1=\mathrm{C} 8$ double, $\mathrm{C} 1=\mathrm{C} 8$ single and $\mathrm{C} 2-\mathrm{O} 1$ single bonds indicate that the compound adopts an $\mathrm{OH}$ tautomeric form rather than the NH form in the solid state. The good agreement can be seen between these bond lengths and counterparts in similar $\mathrm{OH}$ form compounds in the literature [40, 41]. The harmonic oscillator model of aromaticity, the HOMA index, is also a sign of the aromaticity of a ring, which is why we calculated the HOMA indices for both rings using the following equation $[42,43]$ :

$$
\mathrm{HOM} \mathrm{A}=1-\left\lceil\frac{1}{\mathrm{n}} \sum_{i=1}^{n} \alpha_{i}\left(R_{i}-R_{o p t}\right)^{2}\right\rceil
$$


where $n$ is the number of bonds in the molecular fragments interested (in our case $\mathrm{n}$ is equal to 6 for the six-membered rings), the $\alpha_{\mathrm{i}}$ normalization constant is equal to 257.7 and $R_{\text {opt }}$ is equal to $1.388 \AA$ for $\mathrm{C}-\mathrm{C}$ bonds. For the purely aromatic systems, the HOMA index is equal to 1 and for the nonaromatic ones are equal to 0 . As expected, the calculated indices of $\mathrm{C} 1 / \mathrm{C} 6$ and $\mathrm{C} 9 / \mathrm{C} 14$ rings are 0.950 and 0.995 , respectively. The title compound displays a strong intramolecular interaction, in- cluding the $\mathrm{O} 1$ and $\mathrm{N} 1$ atoms. This type of intramolecular hydrogen bonds is a common feature of $o$-hydroxysalicylidene systems $[44,45]$. The $\mathrm{O}-\mathrm{H}$, $\mathrm{H} \ldots \mathrm{N}, \mathrm{O} \ldots \mathrm{N}$ and $\mathrm{O}-\mathrm{H} . . \mathrm{N}$ values of the bond are 0.87 (3) $\AA, 1.82$ (2) $\AA, 2.62$ (2) $\AA$ and 152.00 (3) , respectively. It can be seen from Fig. 2 that this strong hydrogen bond constitutes a $\mathrm{S}(6)$ ring. In the three-dimensional network, the crystal structure is stabilized by weak Van der Waals interactions.

Table 2

Selected geometric parameters for (E)-5-methoxy-2-[(3,4-dimethylphenylimino)methyl]phenol

\begin{tabular}{|c|c|c|c|c|c|c|}
\hline \multirow[t]{3}{*}{ Parameters } & \multirow[t]{3}{*}{ X-ray } & \multicolumn{5}{|c|}{ "DFT B3LYP/6-311+G(d,p) } \\
\hline & & \multirow[b]{2}{*}{ Gas } & \multicolumn{2}{|c|}{$\mathrm{OH}$} & & \multirow{2}{*}{$\begin{array}{l}\mathrm{NH} \\
\text { Gas }\end{array}$} \\
\hline & & & Benzene & EtOH & DMSO & \\
\hline \multicolumn{7}{|c|}{ Bond lengths $(\AA)$} \\
\hline $\mathrm{N} 1 \mathrm{C} 8$ & $1.283(2)$ & 1.291 & 1.291 & 1.292 & 1.293 & 1.332 \\
\hline $\mathrm{C} 2 \mathrm{O} 1$ & $1.343(2)$ & 1.340 & 1.343 & 1.347 & 1.347 & 1.261 \\
\hline $\mathrm{C} 1 \mathrm{C} 8$ & $1.442(2)$ & 1.443 & 1.444 & 1.445 & 1.445 & 1.391 \\
\hline $\mathrm{C} 1 \mathrm{C} 2$ & $1.408(2)$ & 1.419 & 1.419 & 1.418 & 1.418 & 1.470 \\
\hline C1 C6 & $1.403(2)$ & 1.410 & 1.410 & 1.410 & 1.410 & 1.429 \\
\hline C5 C6 & $1.367(2)$ & 1.377 & 1.377 & 1.378 & 1.378 & 1.360 \\
\hline $\mathrm{C} 4 \mathrm{C} 5$ & $1.394(2)$ & 1.409 & 1.409 & 1.409 & 1.409 & 1.433 \\
\hline $\mathrm{C} 3 \mathrm{C} 4$ & $1.382(2)$ & 1.392 & 1.393 & 1.394 & 1.394 & 1.374 \\
\hline $\mathrm{C} 2 \mathrm{C} 3$ & $1.394(2)$ & 1.399 & 1.399 & 1.398 & 1.398 & 1.437 \\
\hline $\mathrm{C} 4 \mathrm{O} 2$ & $1.360(2)$ & 1.357 & 1.357 & 1.358 & 1.358 & 1.356 \\
\hline $\mathrm{C} 7 \mathrm{O} 2$ & $1.417(2)$ & 1.424 & 1.427 & 1.431 & 1.431 & 1.424 \\
\hline O1 H1 & $0.870(2)$ & 0.997 & 0.999 & 1.002 & 1.003 & - \\
\hline N1 H1 & - & - & - & - & - & 1.040 \\
\hline \multicolumn{7}{|l|}{ Bond angles $\left({ }^{\circ}\right)$} \\
\hline $\mathrm{C} 1 \mathrm{C} 2 \mathrm{O} 1$ & $121.2(2)$ & 121.5 & 121.3 & 121.0 & 121.0 & 121.4 \\
\hline $\mathrm{C} 3 \mathrm{C} 2 \mathrm{O} 1$ & $118.4(2)$ & 118.0 & 118.1 & 118.2 & 118.2 & 121.8 \\
\hline C1 C8 N1 & $122.4(2)$ & 122.4 & 122.2 & 121.9 & 121.8 & 123.0 \\
\hline C8 N1 C9 & $121.1(2)$ & 121.3 & 121.3 & 121.4 & 121.6 & 127.9 \\
\hline $\mathrm{C} 5 \mathrm{C} 4 \mathrm{O} 2$ & $114.5(2)$ & 115.3 & 115.4 & 115.4 & 115.4 & 113.6 \\
\hline $\mathrm{C} 3 \mathrm{C} 4 \mathrm{O} 2$ & $124.5(2)$ & 123.9 & 123.9 & 123.8 & 123.8 & 124.6 \\
\hline C2-O1-H1 & $105.9(2)$ & 107.2 & 107.0 & 106.7 & 106.7 & - \\
\hline \multicolumn{7}{|c|}{ Torsion angles $\left(^{\circ}\right)$} \\
\hline C6 C1 C8 N1 & $-175.7(2)$ & 179.4 & 179.5 & 179.6 & 179.4 & 179.9 \\
\hline C9 N1 C8 C1 & $179.4(2)$ & 176.9 & 177.0 & 177.1 & 177.1 & 178.6 \\
\hline C14 C9 N1 C8 & $170.1(2)$ & 146.8 & 147.1 & 149.0 & 150.8 & 169.3 \\
\hline
\end{tabular}

\subsection{Optimized geometries of tautomers and intramolecular proton transfer process}

Table 2 also shows selected B3LYP/6$311+\mathrm{G}(\mathrm{d}, \mathrm{p})$ calculated geometrical parameters for both the $\mathrm{OH}$ and $\mathrm{NH}$ tautomers, besides the experimental ones. There are no significant differences between the experimental and calculated geometrical parameters of the $\mathrm{OH}$ form, except for the torsion angles. The planarity of the molecular geometry for the title compound is related with the torsion angles listed in last three rows of Table 2. The dihedral angle between two six-membered rings is $36.6^{\circ}$ for the optimized $\mathrm{OH}$ tautomer according to the DFT calculations. The differences observed between the geometries of the experimental and calculated counterparts are caused by underestimating the intermolecular interactions. 
DFT and similar calculations cannot take the intermolecular hydrogen bonds, van der Waals or dipole-dipole-like interactions into account and consider molecules in the gas phase (in vacuo), but in reality, the experimental results belong to the solid state consisting of interacting molecules.

Table 3 reflects the total energies, frontier orbital energies and dipole moments of both tautomeric forms of the title compound in the gas phase and also in various solvents for the $\mathrm{OH}$ form. The total energies of the tautomers suggest that the $\mathrm{OH}$ form is more stable than the $\mathrm{NH}$ form by $\sim 2.4$ $\mathrm{kcal} / \mathrm{mol}$ in the gas phase. It is not surprising that the $\mathrm{OH}$ form has two aromatic rings corresponding to a more delocalized $\pi$-electronic system and generally $o$-hydroxy salicylideneanilines are observed in the $\mathrm{OH}$ tautomeric form. The additional information available in the table is regarding the behavior of the $\mathrm{OH}$ tautomer in several solvents. The interactions between the solute and solvent molecules influence the molecular geometry, vibrational frequencies, total energy, electronic spectrum and so on $[46,47]$. The total energy of the title molecule decreases with the increasing polarity of solvent. The lessening of the total energy increases the stability of the molecule. Contrary to the total energy, the energy gap between the LUMOs and HOMOs and the dipole moment increase with the increasing polarity of solvent. The charge delocalization over the molecule skeleton increases and causes the dipole moment to increase.

Table 3

Calculated energies, frontier orbital energies and dipole moments in the gas phase and various solvents

\begin{tabular}{lllll}
\hline \hline & $\mathrm{E}_{\text {total }}(\mathrm{kcal} / \mathrm{mol})$ & $\mathrm{E}_{\mathrm{LUMO}}(\mathrm{eV})$ & $\mathrm{E}_{\text {HOMO }}(\mathrm{eV})$ & $\mu(\mathrm{D})$ \\
\hline OH form & & & & \\
Gas & -517927.0356 & -1.7469 & -5.7946 & 0.7568 \\
Benzene & -517930.3706 & -1.7834 & -5.8354 & 1.0740 \\
EtOH & -517935.2456 & -1.8563 & -5.9062 & 1.6666 \\
DMSO & -517935.5350 & -1.8726 & -5.9062 & 1.7193 \\
\hline NH form & & & & \\
Gas & -517924.6259 & -2.0618 & -5.5304 & 2.6970 \\
\hline \hline
\end{tabular}

In order to investigate its effects on molecular geometry, the intramolecular proton transfer was investigated in the gas phase for the title compound by performing a PES scan at the B3LYP/6$311+\mathrm{G}(\mathrm{d}, \mathrm{p})$ level. Such an intramolecular proton transfer turns the $\mathrm{OH}$ tautomer into the $\mathrm{NH}$ tautomer, leading to important changes in the character of the molecule. The process was started from the gas phase optimized $\mathrm{OH}$ geometry by assigning the $\mathrm{O} 1-\mathrm{H} 1$ bond as a redundant internal coordinate. The relative energy versus the redundant coordinate $\mathrm{O} 1-\mathrm{H} 1$ bond distance in the PES scan process can be seen in Figure 3. The relative energy values are calculated with respect to the energy of the stable $\mathrm{OH}$ tautomer.

In Figure 3, there are two minima representing the $\mathrm{OH}$ and $\mathrm{NH}$ stable forms of the title molecule. The stable NH form is represented by a local minimum with a relative energy of $2.4 \mathrm{kcal} / \mathrm{mol}$ and the stable $\mathrm{OH}$ form corresponds to the global minimum. As can be seen from the potential energy curve, $4.9 \mathrm{kcal} / \mathrm{mol}$ of potential energy is needed to transform the molecule from the $\mathrm{OH}$ form to the NH form.

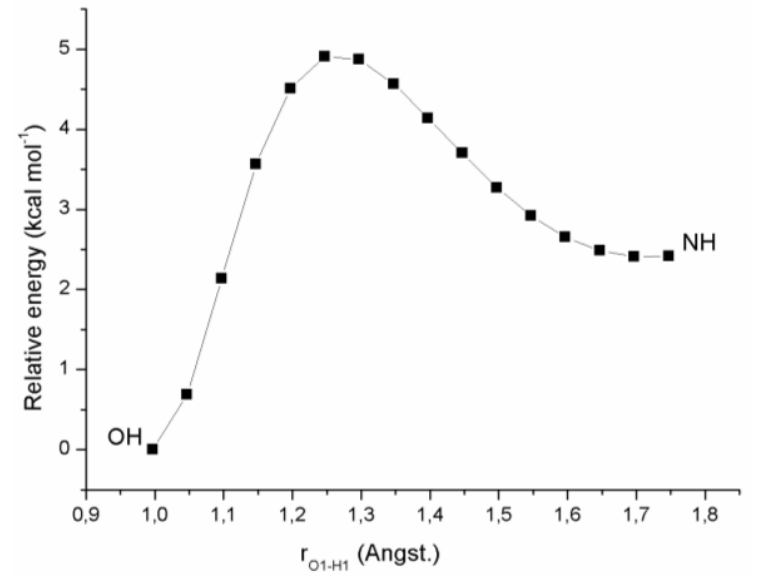

Fig. 3. Relative energy versus the redundant coordinate in the PES scan process

The effects of the intramolecular proton transfer on the molecular geometry can be clearly seen by examining the changes in the indicative bond lengths and HOMA index of the C1/C6 ring for every step in the scan process. Fig. 4 represents the changes occurring in the lengths of the $\mathrm{C} 2-\mathrm{O} 1$ single, $\mathrm{C} 1-\mathrm{C} 8$ single and $\mathrm{C} 8=\mathrm{N} 1$ double bonds 
during the transfer process. Bond lengths of $\mathrm{C} 2-\mathrm{O} 1$ $(1.339 \AA), \mathrm{C} 1-\mathrm{C} 8(1.443 \AA)$ and $\mathrm{C} 8=\mathrm{N} 1(1.291 \AA)$ belonging to the stable $\mathrm{OH}$ tautomer were found as $1.259,1.390$ and $1.333 \AA$ after the fifteen step of the scan where the stable $\mathrm{NH}$ tautomer was observed.

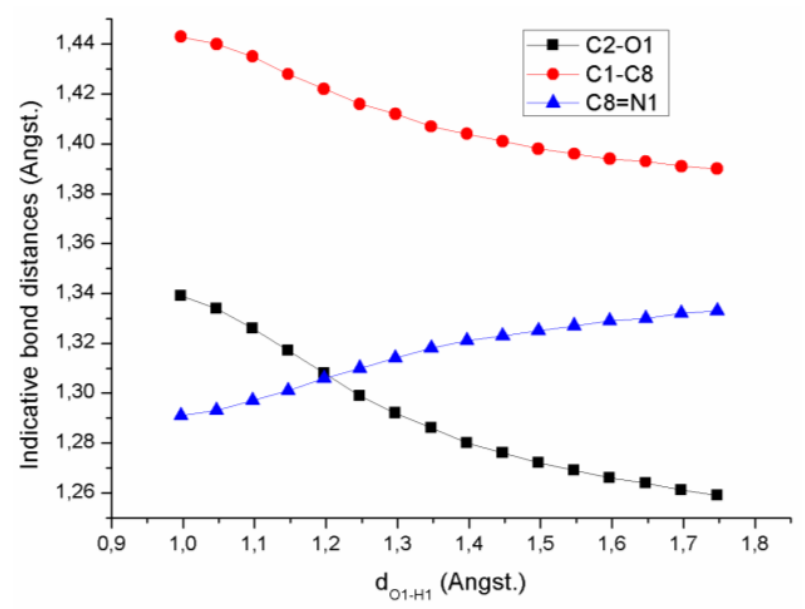

Fig. 4. Selected bond distances versus the redundant coordinate in the PES scan process

The figure clearly indicates that the intramolecular proton transfer affects the double and single characters of these bonds. The HOMA indices of the $\mathrm{C} 1 / \mathrm{C} 6$ and $\mathrm{C} 9 / \mathrm{C} 14$ rings were calculated at every step of the scan process. Fig. 5 shows the changes of HOMA indices in terms of the scan coordinate. The aromaticity level of the $\mathrm{C} 1 / \mathrm{C} 6$ ring decreases while the aromaticity level of the C9/C14 ring remains stable with the scan coordinate going from $0.997 \AA$ to $1.747 \AA$, as expected.

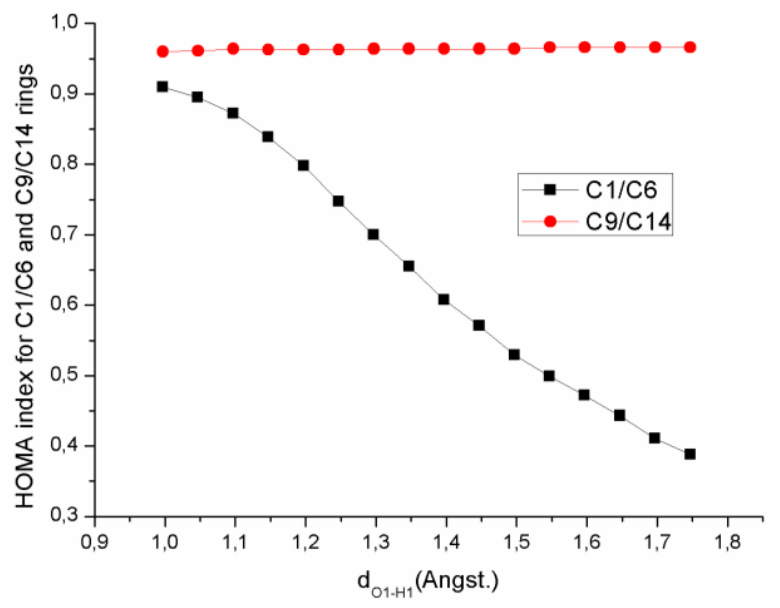

Fig. 5. HOMA indices of the rings of the molecule versus the redundant coordinate in the PES scan process.

\subsection{Electronic absorption spectra}

The UV-Vis electronic spectra of the title compound in benzene, EtOH and DMSO were measured within a $200-500 \mathrm{~nm}$ range at room temperature. The characteristic UV-Vis absorption bands of the molecule can be seen in Figure 6 .

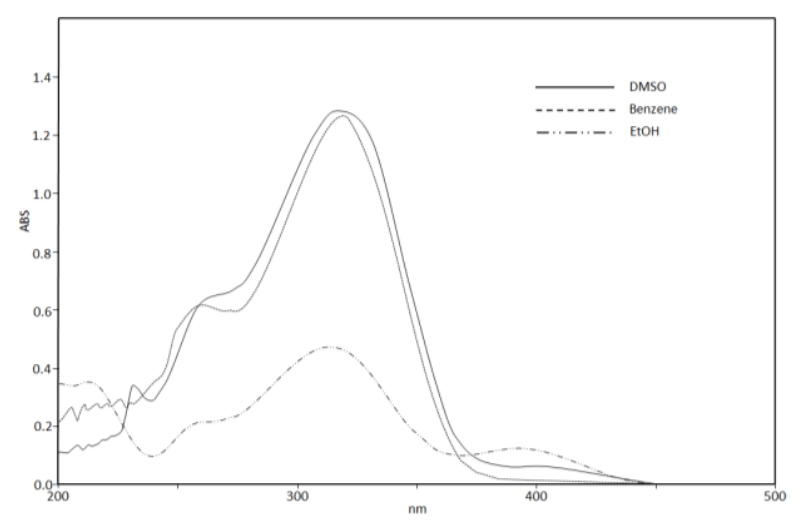

Fig. 6. Experimental UV-Vis spectra of the title compound

In the UV-Vis spectra of ortho-hydroxy Schiff base compounds, the presence of an absorption band at $<400 \mathrm{~nm}$ indicates the $\mathrm{OH}$ tautomeric form. Alternatively, compounds that adopt the $\mathrm{NH}$ tautomeric form show a new absorption band at $>$ $400 \mathrm{~nm}[48,49]$. According to the experimental absorption spectra, the molecule exhibits absorption bands at 318 and $258 \mathrm{~nm}$ in benzene, at 212, 258, 318 and $392 \mathrm{~nm}$ in EtOH and at 232, 260, 318 and $400 \mathrm{~nm}$ in DMSO. Experimental spectra of the title compound show no absorption peak above $400 \mathrm{~nm}$ for these three solutions. The absence of the peaks above $400 \mathrm{~nm}$ clearly indicates that the compound adopts the $\mathrm{OH}$ tautomeric form, even in solution. The theoretical electronic excitation energies, oscillator strengths and nature of the first ten spin-allowed singlet-singlet excitations were calculated by the TD-DFT method for the same solvents. The major contributions of the transitions were designated with the aid of the SWizard program [50]. The experimental and calculated results of the UV-Vis spectral data are listed in Table 4.

The results obtained by the TD-DFT calculations show the absorption bands at near 370 and $280 \mathrm{~nm}$. In view of the calculated absorption spectra of the $\mathrm{OH}$ form, the maximum absorption wavelength corresponds to the electronic transition from the HOMO to the LUMO with an $86 \%$ contribution. The other wavelengths with major contributions can be seen in Table 4 . 
T a ble 4

Experimental and calculated electronic transitions of the title compound in benzene, EtOH and DMSO

\begin{tabular}{|c|c|c|c|}
\hline & Experimental & "DFT/B3LYP/6-311+G(d,p) & \\
\hline & $\lambda(\mathrm{nm})[\mathrm{A}]$ & $\lambda(\mathrm{nm})[\mathrm{f}]$ & Major contributions \\
\hline \multirow[t]{14}{*}{ Benzene } & $318[1.270]$ & $348[0.899]$ & $\mathrm{H} \rightarrow \mathrm{L}(86 \%)$ \\
\hline & $258[0.625]$ & $301[0.020]$ & $\mathrm{H}-1 \rightarrow \mathrm{L}(84 \%)$ \\
\hline & & $283[0.003]$ & $\mathrm{H}-2 \rightarrow \mathrm{L}(49 \%)$ \\
\hline & & & $\mathrm{H}-3 \rightarrow \mathrm{L}(31 \%)$ \\
\hline & & & $\mathrm{H} \rightarrow \mathrm{L}+1(14 \%)$ \\
\hline & & $278[0.163]$ & $\mathrm{H}-3 \rightarrow \mathrm{L}(43 \%)$ \\
\hline & & & $\mathrm{H}-2 \rightarrow \mathrm{L}(28 \%)$ \\
\hline & & & $\mathrm{H} \rightarrow \mathrm{L}+2(10 \%)$ \\
\hline & & $253[0.031]$ & $\mathrm{H} \rightarrow \mathrm{L}+1(54 \%)$ \\
\hline & & & $\mathrm{H} \rightarrow \mathrm{L}+2(13 \%)$ \\
\hline & & & $\mathrm{H}-4 \rightarrow \mathrm{L}(12 \%)$ \\
\hline & & $250[0.207]$ & $\mathrm{H} \rightarrow \mathrm{L}+2(43 \%)$ \\
\hline & & & $\mathrm{H} \rightarrow \mathrm{L}+1(19 \%)$ \\
\hline & & & $\mathrm{H}-4 \rightarrow \mathrm{L}(15 \%)$ \\
\hline \multirow[t]{12}{*}{$\mathrm{EtOH}$} & $392[0.124]$ & $344[0.871]$ & $\mathrm{H} \rightarrow \mathrm{L}(85 \%)$ \\
\hline & $314[0.468]$ & $299[0.013]$ & $\mathrm{H}-1 \rightarrow \mathrm{L}(82 \%)$ \\
\hline & $258[0.212]$ & $283[0.003]$ & $\mathrm{H}-2 \rightarrow \mathrm{L}(66 \%)$ \\
\hline & & & $\mathrm{H}-3 \rightarrow \mathrm{L}(15 \%)$ \\
\hline & $212[0.350]$ & $277[0.168]$ & $\mathrm{H}-3 \rightarrow \mathrm{L}(56 \%)$ \\
\hline & & & $\mathrm{H}-2 \rightarrow \mathrm{L}(13 \%)$ \\
\hline & & $252[0.018]$ & $\mathrm{H} \rightarrow \mathrm{L}+2(49 \%)$ \\
\hline & & & $\mathrm{H}-4 \rightarrow \mathrm{L}(18 \%)$ \\
\hline & & & $\mathrm{H} \rightarrow \mathrm{L}+1(13 \%)$ \\
\hline & & $249[0.203]$ & $\mathrm{H} \rightarrow \mathrm{L}+1(58 \%)$ \\
\hline & & & $\mathrm{H}-4 \rightarrow \mathrm{L}(14 \%)$ \\
\hline & & & $\mathrm{H}-2 \rightarrow \mathrm{L}(7 \%)$ \\
\hline \multirow[t]{14}{*}{ DMSO } & $400[0.090]$ & $346[0.898]$ & $\mathrm{H} \rightarrow \mathrm{L}(86 \%)$ \\
\hline & 318 [1.277] & $299[0.014]$ & $\mathrm{H}-1 \rightarrow \mathrm{L}(82 \%)$ \\
\hline & $260[0.635]$ & $284[0.003]$ & $\mathrm{H}-2 \rightarrow \mathrm{L}(67 \%)$ \\
\hline & & & $\mathrm{H}-3 \rightarrow \mathrm{L}(15 \%)$ \\
\hline & & & $H \rightarrow L+2(8 \%)$ \\
\hline & $232[0.348]$ & 277 [0.169] & $\mathrm{H}-3 \rightarrow \mathrm{L}(57 \%)$ \\
\hline & & & $\mathrm{H}-2 \rightarrow \mathrm{L}(13 \%)$ \\
\hline & & & $\mathrm{H} \rightarrow \mathrm{L}+1(8 \%)$ \\
\hline & & $252[0.019]$ & $\mathrm{H} \rightarrow \mathrm{L}+2(53 \%)$ \\
\hline & & & $\mathrm{H}-4 \rightarrow \mathrm{L}(18 \%)$ \\
\hline & & & $\mathrm{H} \rightarrow \mathrm{L}+1(9 \%)$ \\
\hline & & $249[0.216]$ & $\mathrm{H} \rightarrow \mathrm{L}+1(61 \%)$ \\
\hline & & & $\mathrm{H}-4 \rightarrow \mathrm{L}(13 \%)$ \\
\hline & & & $\mathrm{H}-2 \rightarrow \mathrm{L}(7 \%)$ \\
\hline
\end{tabular}

\subsection{Vibrational frequencies}

The FT-IR spectrum of the title compound is given in Fig. 7, with the experimental and scaled computational vibrational frequencies of the compound compared in Table 5.

The O-H stretching can be attributed to the remarkable absorption band in the $2000-3000 \mathrm{~cm}^{-1}$ region in the experimental spectrum. The intramolecular and intermolecular hydrogen bond formations affect the $\mathrm{O}-\mathrm{H}$ stretching vibration. The strong intramolecular hydrogen bond between the $\mathrm{O} 1$ and $\mathrm{N} 1$ atoms of the title molecule causes this phenomenon here and the experimental vibrational frequency of O-H stretching is shifted and widened to the $2000-3000 \mathrm{~cm}^{-1}$ range.

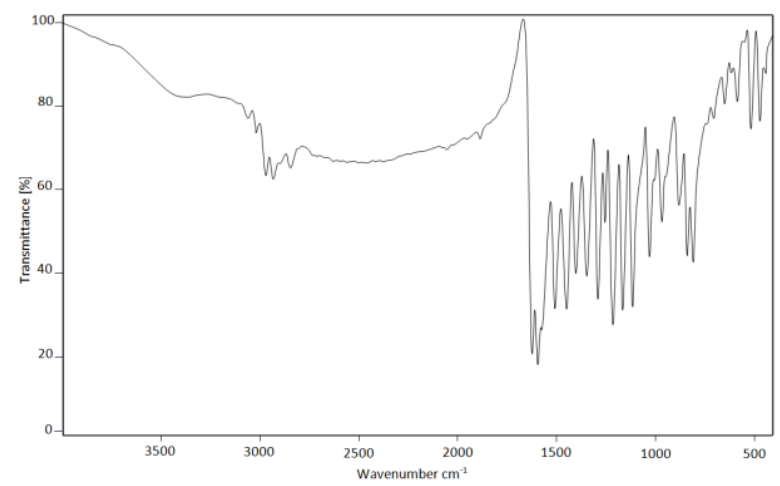

Fig. 7. Experimental FT-IR spectrum of the title compound 
The $\mathrm{O}-\mathrm{H}$ in-plane and out-of-plane bending vibrations are located at 1343 and $794 \mathrm{~cm}^{-1}$, respectively. The band located at $1620 \mathrm{~cm}^{-1}$ can be attributed to $\mathrm{C}=\mathrm{N}$ stretching. The spectrum also shows the presence of C-O stretching at $1213 \mathrm{~cm}^{-1}$. While the absorption bands located at $2833-2906 \mathrm{~cm}^{-1}$ region belong to symmetric $\mathrm{CH}_{3}$ stretching, the bands of asymmetric $\mathrm{CH}_{3}$ stretching can be seen in the
2931-2967 $\mathrm{cm}^{-1}$ region. Table 5 shows the other vibrational frequencies and scaled computational vibrational frequencies of the compound. These frequency values are in good agreement with the literature [51, 52]. The theoretical results obtained from DFT calculations show good agreement with the experimental values, except for the $\mathrm{O}-\mathrm{H}$ stretching.

Table 5

Experimental and calculated vibrational frequencies of $I R$ spectra $\left(\mathrm{cm}^{-1}\right)$

\begin{tabular}{lcc}
\hline \hline Assignments & Experimental & DFT/B3LYP/6-311+G(d,p) \\
\hline Aromatic $\mathrm{CH}$ out of plane bending & $807-835$ & $786-795$ \\
Aromatic $\mathrm{CH}$ bending & 1025 & 1018 \\
$\mathrm{CO}$ stretching & 1213 & 1219 \\
$\mathrm{OH}$ bending & 1343 & 1388 \\
Symmetric $\mathrm{CH}_{3}$ bending & 1397 & 1366 \\
Asymmetric $\mathrm{CH}_{3}$ bending & 1448 & 1449 \\
Aromatic $\mathrm{CC}$ stretching & 1590 & 1547 \\
$\mathrm{CN}$ stretching & 1620 & 1610 \\
$\mathrm{OH}$ stretching & 2455 & 3038 \\
Symmetric $\mathrm{CH}_{3}$ stretching & $2833-2906$ & 2918 \\
Asymmetric $\mathrm{CH}_{3}$ stretching & $2931-2967$ & 2962 \\
Aromatic $\mathrm{CH}_{\text {stretching }}$ & 3012 & 3056 \\
\hline \hline
\end{tabular}

\section{5. ${ }^{1}$ H NMR spectra}

The ${ }^{1} \mathrm{H}-\mathrm{NMR}$ spectrum of the title compound was recorded in DMSO- $d_{6}$ and can be seen in Fig. 8. The resonance of the hydroxyl proton is at $13.86 \mathrm{ppm}$. As expected, this is typical for protons involved in intramolecular hydrogen bonding. The resonance of the imino proton is at $8.82 \mathrm{ppm}$. The absorption peaks of aromatic ring protons are between 6 and $8 \mathrm{ppm}$. The $\mathrm{H} 3$ proton is coupled to the $\mathrm{H} 5$ proton and shows doublet peaks at 6.47 $\operatorname{ppm}\left(J_{3,5}=2.32 \mathrm{~Hz}\right)$. The $\mathrm{H} 5$ proton coupled to $\mathrm{H} 6$ shows a doublet and gives another doublet by coupling to $\mathrm{H} 3$ at $6.53 \mathrm{ppm}\left(J_{5,6}=8.6 \mathrm{~Hz}, J_{5,3}=2.32\right.$ $\mathrm{Hz})$. The $\mathrm{H} 6$ proton is coupled to the $\mathrm{H} 5$ proton and shows a doublet at $7.5 \mathrm{ppm}\left(J_{6,5}=8.6 \mathrm{~Hz}\right)$. The $\mathrm{H} 8$ proton is coupled to the $\mathrm{H} 12$ proton and shows doublet peaks at $7.17 \mathrm{ppm}\left(J_{8,12}=2.76 \mathrm{~Hz}\right)$. The H12 proton coupled to H11 shows a doublet and gives another doublet by coupling to $\mathrm{H} 8$ at 7.11 $\operatorname{ppm}\left(J_{12,11}=8 \mathrm{~Hz}, J_{12,8}=2.76 \mathrm{~Hz}\right)$. The $\mathrm{H} 11$ proton is coupled to the H12 proton and shows a doublet at $7.18 \mathrm{ppm}$. The resonances of the H15, H16 and $\mathrm{H} 17$ protons are at 2.22, 2.25 and $3.80 \mathrm{ppm}$, respectively. The absorption of ring protons is in the range of 6-8 ppm, which corresponds to an aromatic character. These results are in a good agreement with the literature and also show that the title compound adopts an $\mathrm{OH}$ form in solution $[40,51]$.

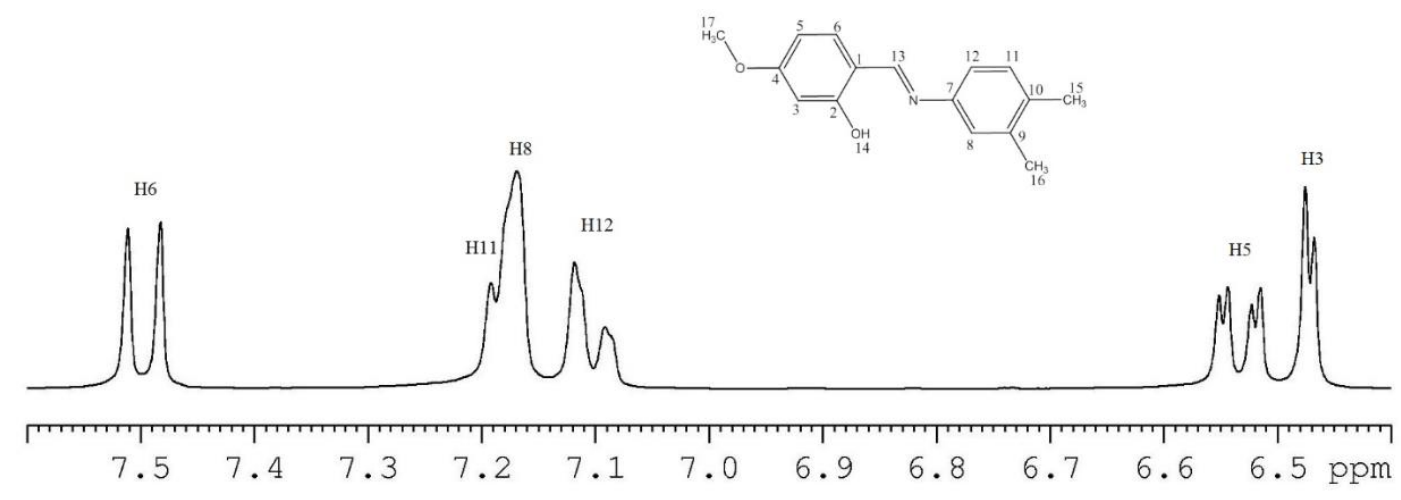

Fig. 8. Experimental ${ }^{1} \mathrm{H}$ NMR spectrum of the title compound 


\subsection{Second-order $N L O$ properties}

The NLO properties of a molecule, which can be predicted by quantum chemical calculations, play an important role for the design of new materials in communication, signal processing and optical interconnection technologies [53]. In particular, organic molecules are studied frequently because of their larger NLO susceptibilities, with $\pi$-electron cloud movement from donor to acceptor, fast NLO response times, high laser damage thresholds and low dielectric constants. In addition to these advantages, the organic molecules also have disadvantages, including generally low thermal stability, facile relaxation to random orientations and in the UV-Vis region, the low energy transitions result in a trade-off between their nonlinear efficiency and optical transparency [54-56]. The usage of organic molecules as ligands can overcome the disadvantages. Their usage as ligands allows the Schiff base compounds to be investigated for this field.

The average linear polarizability $\bar{\alpha}$ and the first hyperpolarizability $\beta$ can be calculated by using the Eqs. (2) and (3), respectively [53]:

$$
\begin{gathered}
\bar{\alpha}=\frac{1}{3}\left(\alpha_{x x}+\alpha_{y y}+\alpha_{z z}\right) \\
\beta=\left[\left(\beta_{x x x}+\beta_{x y y}+\beta_{x z z}\right)^{2}+\left(\beta_{y y y}+\beta_{x y y}+\beta_{y z z}\right)^{2}+\left(\beta_{z z z}+\beta_{x x z}+\beta_{y z}\right)^{2}\right]^{1 / 2}
\end{gathered}
$$

In order to investigate the NLO properties of the title compound, the components of dipole moment, polarizability and the first hyperpolarizability have been calculated using polar = ENONLY input to Gaussian03 at the level of B3LYP/6$311+\mathrm{G}(\mathrm{d}, \mathrm{p})$ in the gas phase. The components and calculated values of the average linear polarizability $\bar{\alpha}$ and the first hyperpolarizability $\beta$ are listed in Table 6.

The calculated values of components show a difference depending on the size of the basis sets used. However, it is difficult to decide which basis set generates reliable values because there are no reported experimental values for the title compound in the literature. For this reason, we used the basis set $6-311+\mathrm{G}(\mathrm{d}, \mathrm{p})$ in all this work. The calculated $\beta$ components have been converted into electrostatic units esu $\left(1 \mathrm{au}=8.6393 \times 10^{-33} \mathrm{esu}\right)$. The values of $\bar{\alpha}$ and $\beta$ obtained by Sun et al. with the B3LYP/6-31G(d) method for urea are $3.831 \AA^{3}$ and $0.372 \times 10^{-30} \mathrm{esu}$, respectively, and generally used for the comparison [57]. In present work, the value of $\bar{\alpha}$ is $126.634 \AA^{3}$ and the value of $\beta$ is
$107.516 \times 10^{-30}$ esu for the title molecule. The movement of the $\pi$-electron cloud must be responsible for the increasing conjugation, and hence an increase in the NLO properties of the molecule. According to the high value of the first hyperpolarizability, the title compound could be an excellent applicant in the development of NLO materials.

\section{Table 6}

Calculated polarizability $\left(\AA^{3}\right)$ and the first hyperpolarizability $\left(\times 10^{-30}\right.$ esu $)$ components for

(E)-5-methoxy-2-[(3,4-dimethylphenylimino)methyl]phenol

\begin{tabular}{cc}
\hline \hline $\boldsymbol{\alpha}_{x x}$ & 60.4372 \\
$\boldsymbol{\alpha}_{x y}$ & -0.4112 \\
$\boldsymbol{\alpha}_{y y}$ & 28.9580 \\
$\boldsymbol{\alpha}_{x z}$ & 0.2703 \\
$\boldsymbol{\alpha}_{y z}$ & -0.0925 \\
$\boldsymbol{\alpha}_{z z}$ & 18.3818 \\
$\boldsymbol{\beta}_{x x x}$ & -11.0507 \\
$\boldsymbol{\beta}_{x x y}$ & -3.2233 \\
$\boldsymbol{\beta}_{x y y}$ & 1.1893 \\
$\boldsymbol{\beta}_{\boldsymbol{y y y}}$ & -0.8852 \\
$\boldsymbol{\beta}_{x x z}$ & 1.1907 \\
$\boldsymbol{\beta}_{\boldsymbol{x y z}}$ & -0.4443 \\
$\boldsymbol{\beta}_{y y z}$ & 0.2199 \\
$\boldsymbol{\beta}_{x z z}$ & 0.1499 \\
$\boldsymbol{\beta}_{\boldsymbol{y} z z}$ & -0.2689 \\
$\boldsymbol{\beta}_{z z z}$ & 0.0458 \\
\hline \hline
\end{tabular}

\subsection{Thermodynamic properties}

The standard thermodynamic functions, such as enthalpy $\left(H_{m}^{0}\right)$, entropy $\left(S_{m}^{0}\right)$, heat capacity $\left(C_{p, m}^{0}\right)$, thermal energy (E) and their components, were computed at constant pressure (by changing the temperature) and temperature (by changing the pressure) in the gas phase with the B3LYP/6$311 \mathrm{G}+(\mathrm{d}, \mathrm{p})$ level of theory. The changes of all thermodynamic functions at various temperatures and pressures in the range of $100.00-500.00 \mathrm{~K}$ and 1.00-5.00 atm are given in Table 7. The total energy of a molecular system is the sum of the translation, electronic, rotational and vibrational energies. To obtain the total energy of the molecule, the contribution of these energy values to the thermal energy, heat capacity and entropy values were obtained. In addition, the component of rotational temperatures and constants were calculated (see Table 7). The values of thermal energy components are the same at all pressures but change with changing temperature. These values are 0.000 for 
T a ble 7

Calculated thermodynamic components for (E)-5-methoxy-2-[(3,4-dimethylphenylimino)methyl]phenol

\begin{tabular}{|c|c|c|c|c|c|c|c|}
\hline & & $\begin{array}{l}\text { Thermal } \\
\text { energy, E } \\
\text { (cal/mol K) }\end{array}$ & $\begin{array}{l}C_{p, m}^{0} \\
(\mathbf{c a l} / \mathbf{m o l ~ K})\end{array}$ & $\begin{array}{l}S_{m}^{0} \\
(\mathbf{c a l} / \mathbf{m o l ~ K})\end{array}$ & $P(a t m)=1$ & & $\begin{array}{l}H_{m}^{0} \\
\text { (kcal/mol) }\end{array}$ \\
\hline \multirow{20}{*}{$\begin{array}{l}\text { electronic } \\
\text { translational } \\
\text { rotational } \\
\text { vibrational } \\
\text { total }\end{array}$} & \multirow[t]{5}{*}{$\mathrm{T}(\mathrm{K})=100$} & 0.000 & 0.000 & 0.000 & & 0.000 & 1.830 \\
\hline & & 0.889 & 2.981 & 37.083 & & 42.510 & \\
\hline & & 0.889 & 2.981 & 30.732 & & 33.988 & \\
\hline & & 193.842 & 21.602 & 18.265 & & 59.988 & \\
\hline & & 195.620 & 27.564 & 86.080 & & 136.487 & \\
\hline & \multirow[t]{5}{*}{150} & 0.000 & 0.000 & 0.000 & 1.5 & 0.000 & 3.566 \\
\hline & & 0.447 & 2.981 & 39.097 & & 41.704 & \\
\hline & & 0.447 & 2.981 & 31.941 & & 33.988 & \\
\hline & & 186.900 & 31.834 & 28.979 & & 59.988 & \\
\hline & & 187.794 & 37.795 & 100.016 & & 135.681 & \\
\hline & \multirow[t]{5}{*}{200} & 0.000 & 0.000 & 0.000 & 2 & 0.000 & 5.805 \\
\hline & & 0.596 & 2.981 & 40.526 & & 41.132 & \\
\hline & & 0.596 & 2.981 & 32.798 & & 33.988 & \\
\hline & & 188.742 & 41.872 & 39.508 & & 59.988 & \\
\hline & & 189.934 & 47.834 & 112.833 & & 135.109 & \\
\hline & \multirow[t]{5}{*}{250} & 0.000 & 0.000 & 0.000 & 2.5 & 0.000 & 8.552 \\
\hline & & 0.745 & 2.981 & 41.635 & & 40.689 & \\
\hline & & 0.745 & 2.981 & 33.463 & & 33.988 & \\
\hline & & 191.091 & 52.132 & 49.949 & & 59.988 & \\
\hline & & 192.581 & 58.093 & 125.048 & & 134.666 & \\
\hline \multirow{30}{*}{ B3LYP } & \multirow{5}{*}{298.150} & 0.000 & 0.000 & 0.000 & & & 11.686 \\
\hline & & 0.889 & 2.981 & 42.510 & & & \\
\hline & & 0.889 & 2.981 & 33.988 & & & \\
\hline & & 193.842 & 62.154 & 59.988 & & & \\
\hline & & 195.620 & 68.116 & 136.486 & & & \\
\hline & \multirow[t]{5}{*}{300} & 0.000 & 0.000 & 0.000 & 3 & 0.000 & 11.889 \\
\hline & & 0.894 & 2.981 & 42.541 & & 40.327 & \\
\hline & & 0.894 & 2.981 & 34.007 & & 33.988 & \\
\hline & & 193.958 & 62.538 & 60.374 & & 59.988 & \\
\hline & & 195.746 & 68.500 & 136.921 & & 134.303 & \\
\hline & \multirow[t]{5}{*}{350} & 0.000 & 0.000 & 0.000 & 3.5 & 0.000 & 15.598 \\
\hline & & 1.043 & 2.981 & 43.306 & & 40.020 & \\
\hline & & 1.043 & 2.981 & 34.466 & & 33.988 & \\
\hline & & 197.342 & 72.781 & 70.788 & & 59.988 & \\
\hline & & 199.429 & 78.743 & 148.560 & & 133.997 & \\
\hline & \multirow[t]{5}{*}{400} & 0.000 & 0.000 & 0.000 & 4 & 0.000 & 19.881 \\
\hline & & 1.192 & 2.981 & 43.970 & & 39.755 & \\
\hline & & 1.192 & 2.981 & 34.864 & & 33.988 & \\
\hline & & 201.228 & 82.546 & 81.150 & & 59.988 & \\
\hline & & 203.612 & 88.508 & 159.985 & & 133.732 & \\
\hline & \multirow[t]{5}{*}{450} & 0.000 & 0.000 & 0.000 & 4.5 & 0.000 & 24.636 \\
\hline & & 1.341 & 2.981 & 44.555 & & 39.521 & \\
\hline & & 1.341 & 2.981 & 35.216 & & 33.988 & \\
\hline & & 205.585 & 91.630 & 91.405 & & 59.988 & \\
\hline & & 208.268 & 97.592 & 171.175 & & 133.498 & \\
\hline & \multirow[t]{5}{*}{500} & 0.000 & 0.000 & 0.000 & 5 & 0.000 & 29.826 \\
\hline & & 1.490 & 2.981 & 45.078 & & 39.312 & \\
\hline & & 1.490 & 2.981 & 35.530 & & 33.988 & \\
\hline & & 210.378 & 99.948 & 101.496 & & 59.988 & \\
\hline & & 213.359 & 105.910 & 182.104 & & 133.288 & \\
\hline
\end{tabular}

electronic, 0.889 for translation and rotational, 193.842 for vibrational and 195.620 for the total energy at all pressures. Otherwise, all the components of the entropy show different values at different temperatures. The translational energy shows different values under varying pressure, but the electronic energy is equal to zero at all pressures. The other two components have the same value at all pressures. It is clear that the thermal energies come from the vibration energy of the greatest contribution. The results show that the standard thermodynamic functions increase with 
increasing temperature, due to the intensities of increasing molecular vibration. It has been shown that the entropy increases, otherwise the enthalpy and heat capacity remain stable, when the pressure is increased at $298.15 \mathrm{~K}$. Finally, the calculated zero-point vibrational energy, the components of rotational temperatures and constants for the title compound are $184.52595 \mathrm{Kcal} / \mathrm{mol}$; 0.06715, 0.0610 , $0.0569 \mathrm{~K}$ and $1.39911,0.12700,0.11861 \mathrm{GHz}$ at all the temperatures and pressures, respectively.

\section{CONCLUSIONS}

In this study, we synthesized a Schiff base compound, (E)-5-methoxy-2-[(3,4-dimethylphenylimino)methyl]phenol, and characterized it by spectroscopic, structural and theoretical methods. Xray, FT-IR, UV-Vis and NMR methods confirm the $\mathrm{OH}$ form of the title compound for the gas phase and in solution. The optimized molecular geometry obtained from the DFT B3LYP/6$311+\mathrm{G}(\mathrm{d}, \mathrm{p})$ calculations is very close to the molecular geometry in the solid crystal structure. In the gas phase, the PES scan process shows that the potential barrier to exceed the transition from the $\mathrm{OH}$ tautomeric form to the $\mathrm{NH}$ tautomeric form is $4.9 \mathrm{kcal} / \mathrm{mol}$. This intramolecular proton transfer affects the molecular geometry effectively by changing the aromaticity of the $\mathrm{C1} / \mathrm{C} 6$ ring and indicative bond lengths. The high value of the first hyperpolarizability shows that the title compound can be used as a new material in non-linear optical studies. We hope this study will help researchers to design and synthesize new materials.

\section{REFERENCES}

[1] W. M. F. Fabian, L. Antonov, D. Nedeltcheva, F. S. Kanounah, P. J. Taylor, Tautomerism in hydroxynaphthaldehyde anils and azo analogues: a combined experimental and computational study, J. Phys. Chem., A108 (2004) 7603-7612. DOI: 10.1021/jp048035z

[2] T. M. Krygowski, J. E. Zachara-Horegland, M. Palusiak, S. Pelloni, P. Lazzaretti, Relation between pi-electron localization/delocalization and $\mathrm{H}$-bond strength in derivatives of o-hydroxy-Schiff bases, J. Org. Chem., 73 (2008) 2138-2145. DOI: $10.1021 /$ jo 7023174

[3] V. Bertolasi, P. Gilli, G. Gilli, Crystal Chemistry and Prototropic Tautomerism in 2-(1-Iminoalkyl)- phenols (or naphthols) and 2-Diazenyl-phenols (or naphthols), Curr. Org. Chem., 13 (2009) 250-268. DOI: $10.2174 / 138527209787314841$

[4] B. Kukawska-Tarnawska, A. Les, T. Dziembowska, Z. J. Rozwadowski, Tautomeric forms of N-(5nitrosalicylidene)-2-butylamine: Experimental and theoretical DFT study, J. Mol. Struct., 928 (2009) 25-31. DOI: 10.1016/j.molstruc.2009.03.007
[5] H. Ünver, K. Polat, M. Uçar, D. M. Zengin, Synthesis and keto-enol tautomerism in N-(2-hydroxy-1naphthylidene)anils, Spect. Lett., 36 (4) (2003) 287-301. DOI: $10.1081 /$ SL-120024579

[6] D. Maciejewska, D. Pawlak, V. Koleva, Hydrogen bonding and tautomerism of benzylideneanilines in the solid state, J. Phys. Org. Chem., 12 (1999) 875-880.

[7] H. Karabıyık, H. Petek, N. Ocak-İskeleli, Ç. Albayrak, Structural and aromatic aspects for tautomerism of (Z)6-((4-bromophenylamino)methylene)-2,3-dihydroxycyclohexa-2,4-dienone, Struct. Chem. 20 (2009) 10551065. DOI: $10.1007 / \mathrm{s} 11224-009-9509-\mathrm{x}$

[8] H. Petek, Ç. Albayrak, M. Odabaşoğlu, İ. Şenel, O. Büyükgüngör, The proton transfer process observed in the structure analysis and DFT calculations of (E)-2ethoxy-6-[(2-methoxyphenylimino)methyl]phenol, Struct. Chem., 21 (2010) 681-690. DOI: $10.1007 / \mathrm{s} 11224-010-9598-6$

[9] A. D. Garnovski, A. L. Nivorozhki, V. I. Minkin, Ligand environment and the structure of Schiff base adducts and tetracoordinated metal-chelates, Coord. Chem. Rev., 126 (1993) 1-69. DOI: 10.1016/0010-8545(93)85032-Y

[10] M. Calligaris, L. Randaccio, In: G. Wilkinson (Ed.), Compherensive Coordination Chemistry, Vol 2, Permagon Press, London, pp. 715-738, 1987.

[11] R. H. Lozier, R. A. Bogomolni, W. Stoeckenius, Bacteriorhodopsin: A light-driven proton pump in Halobacterium halobium, Biophys. J., 15, (1975) 955-962. DOI: $10.1016 /$ S0006-3495(75)85875-9

[12] A. Das, M. D. Trousdale, S. Ren, E. J. Lien, Inhibition of herpes simplex virus type 1 and adenovirus type 5 by heterocyclic Schiff bases of aminohydroxyguanidine tosylate, Antiviral Res., 44 (1999) 201-208. DOI: $10.1016 / \mathrm{S} 0166-3542(99) 00070-4$

[13] S. Ren, R. Wang, K. Komatsu, P. Bonaz-Krause, Y. Zyrianow, C. E. McKenna, C. Osipke, Z. A. Tokes, E. J. Lien, Synthesis, biological evaluation, and quantitative structure-activity relationship analysis of new Schiff bases of hydroxysemicarbazide as potential antitumor agents, J. Med. Chem., 45 (2002) 410-419. DOI: $10.1021 / \mathrm{jm} 010252 \mathrm{q}$

[14] S. Ren, Z. A. Tokes, C. Osipke, B. Zhou, Y. Yen, E. J. Lien, Inhibition of tumor cell growth by Schiff bases of hydroxysemicarbazide, Anticancer Res., 21 (2001) 3445-3451.

[15] E. Hadjoudis, M. Vitterakis, I. Moustakali-Mavridis, Photochromism and thermochromism of Schiff-bases in the solid-state and in rigid glasses, Tetrahedron $\mathbf{4 3}$ (1987) 1345-1360. DOI: $10.1016 / \mathrm{S} 0040-4020(01) 90255-8$

[16] E. Hadjoudis, Photochromic and thermochromic anils, Mol. Eng. 5 (4) (1995) 301-337. DOI: $10.1007 / \mathrm{BF} 01004014$

[17] A. P. Alivisatos, P. F. Barbara, A. W. Castleman, J. Chang, D. A. Dixon, M. L. Klein, G. L. McLendon, J. S. Miller, M. A. Ratner, P. J. Rossky, S. I. Stupp, M. E. Thomson, From molecules to materials: Current trends and future directions, Adv. Materials., 10 (16) (1998) 1297-1336. 
[18] L. Dalton, Polymers for photonics applications I, $A d v$. Polym. Sci., 158 (2002) 1-75.

DOI: $10.1007 / 3-540-44608-7$

[19] A. Koll, J. Janski, A. Karpfen, P. Wolschann, Bifunctional influence of 3-chloro substitution on structural and energetic characteristics of N-methyl-salicylidene imines, J. Mol. Struct., 976 (2010) 19-29.

DOI: 10.1016/j.molstruc.2009.12.028

[20] A. Senier, F. G. Shepheard, Studies in phototropy and thermotropy. Part 1. Arylidene and naphthylideneamines, J. Chem. Soc., 95 (1909) 1943-1955. DOI: $10.1039 / \mathrm{CT} 9099501943$

[21] A. Filarowski, A. Kochel, K. Cieslik, A. Koll, Steric and aromatic impact on intramolecular hydrogen bonds in $o$ hydroxyaryl ketones and ketimines, J. Phys. Org. Chem., 18 (2005) 986-993. DOI: 10.1002/poc.942

[22] G. Pavlovic, J. M. Sosa, A 3-[(2-Oxo-1-naphthylidene) methylamino]benzoic acid, Acta Cryst. C56 (2000) 1117-1119. DOI: 10.1107/S0108270100007290

[23] R. Casasnovas, A. Salva, J. Frau, J. Donoso, F. Munoz, Theoretical study on the distribution of atomic charges in the Schiff bases of 3-hydroxypridine-4-aldehyde and alanine. The effect of the protonation state of the pyridine and imine nitrogen atoms, Chem. Phys., 355 (2009) 149-156. DOI: 10.1016/j.chemphys.2008.12.006

[24] H. Ünver, M. Yıldı, Tautomerism in solution and solid state, spectroscopic studies and crystal structure of (Z)-1[(4-amino-2,3,5,6-tetramethylphenylamino)methylene]-1, 8a-dihydronaphthalen-2(3H)-one, Spect. Lett., 43 (2010) 114-121. DOI: 10.1080/00387010903284646

[25] T. Dziembowska, M. Szafran, A. Katrusrak, Z. Raqzwadowski, Crystal structure of and solvent effect on tautomeric equilibrium in Schiff base derived from 2hydroxy-1-napthaldehyde and methylamine studied by X-ray diffraction, DFT, NMR and IR methods, J. Mol. Struct., 929 (2009) 32-42.

DOI: $10.1016 /$ j.molstruc.2009.04.001

[26] H. Petek, Ç. Albayrak, N. Ocak-İskeleli, E. Ağar, İ. Şenel, Crystallographic and conformational analyses of zwitterionic form of (E)-2-methoxy-6-[(2-morpholinoethylimino)methyl]phenolate, J. Chem. Cryst., 37 (2007) 285-290. DOI: 10.1007/s10870-006-9175-4

[27] G. Wojciechowski, M. Ratajczak-Sitarz, A. Katrusiak, W. Schilf, P. Przybylski, B. Brzezinski, Crystal structure of Schiff base derivative of gossypol with 3,6,9-trioxadecylamine, J. Mol. Struct., 650 (2003) 191-199. DOI: $10.1016 / \mathrm{S} 0022-2860(03) 00319-3$

[28] H. Petek, Ç. Albayrak, E. Ağar, H. Kalkan, (Z)-6-[(2Fluorophenyliminio)methylene]-2,3-dihydroxyphenolate, Acta Cryst., E62 (2006) o3685-03687. DOI: $10.1107 / \mathrm{S} 1600536806029606$

[29] Stoe \& Cie, X-AREA (Version 1.18) and X-RED32 (Version 1.04), Darmstadt, Germany, 2002.

[30] G. M. Sheldrick, A short history of SHELX, Acta Cryst. A64 (2008) 112-122. DOI: $10.1107 / \mathrm{S} 0108767307043930$

[31] C. Lee, W. Yang, R. G. Parr, Development of the ColleSalvetti correlation-energy formula into a functional of the electron density, Phys. Rev., B37 (1988) 785-789. DOI: 10.1103/PhysRevB.37.785
[32] A. D. Becke, Density-functional thermochemistry. III. The role of exact exchange, J. Chem. Phys., 98 (1993) 5648-5652. DOI: 10.1063/1.464913

[33] M. J. Frisch, G. W. Trucks, H. B. Schlegel, G. E. Scuseria, M. A. Robb, J. R. Cheeseman, J. A. Montgomery, Jr., T. Vreven, K. N. Kudin, J. C. Burant, J. M. Millam, S. S. Iyengar, J. Tomasi, V. Barone, B. Mennucci, M. Cossi, G. Scalmani, N. Rega, G. A. Petersson, H. Nakatsuji, M. Hada, M. Ehara, K. Toyota, R. Fukuda, J. Hasegawa, M. Ishida, T. Nakajima, Y. Honda, O. Kitao, H. Nakai, M. Klene, X. Li, J. E. Knox, H. P. Hratchian, J. B. Cross, V. Bakken, C. Adamo, J. Jaramillo, R. Gomperts, R. E. Stratmann, O. Yazyev, A. J. Austin, R. Cammi, C. Pomelli, J. W. Ochterski, P. Y. Ayala, K. Morokuma, G. A. Voth, P. Salvador, J. J. Dannenberg, V. G. Zakrzewski, S. Dapprich, A. D. Daniels, M. C. Strain, O. Farkas, D. K. Malick, A. D. Rabuck, K. Raghavachari, J. B. Foresman, J. V. Ortiz, Q. Cui, A. G. Baboul, S. Clifford, J. Cioslowski, B. B. Stefanov, G. Liu, A. Liashenko, P. Piskorz, I. Komaromi, R. L. Martin, D. J. Fox, T. Keith, M. A. Al-Laham, C. Y. Peng, A. Nanayakkara, M. Challacombe, P. M. W. Gill, B. Johnson, W. Chen, M. W. Wong, C. Gonzalez, and J. A. Pople, Gaussian, Inc., Wallingford CT, 2004.

[34] J. Tomasi, B. Mennucci, R. Cammi, Quantum mechanical continuum solvation models, Chem. Rev., 105 (2005) 2999-3093. DOI: $10.1021 / \mathrm{cr} 9904009$

[35] D. Jacquemin, J. Preat, V. Wathelet, M. Fontaine, E. A. Perpete, Thioindigo Dyes: Highly Accurate Visible Spectra with TD-DFT, J. Am. Chem. Soc., 128 (2006) 2072-2083. DOI: 10.1021/ja056676h

[36] N. Santhanamoorthi, K. Senthilkumar, P. Kolandaivel, Tautomerization and solvent effects on the absorption and emission properties of the Schiff base $\mathrm{N} \mathrm{N}^{\prime}-$ bis(salicylidene)-p-phenylenediamine - A TDDFT study, Mol. Phys., 108 (14) (2010) 1817-1827. DOI: $10.1080 / 00268976.2010 .490796$

[37] J. P. Merrick, D. Moran, L. Radom, An evaluation of harmonic vibrational frequency scale factors, J. Phys. Chem., A111 (2007) 11683-11700. DOI: $10.1021 / \mathrm{jp} 073974 \mathrm{n}$

[38] L. J. Farrugia, ORTEP-3 for Windows - a version of ORTEP-III with a Graphical User Interface (GUI), J. Appl. Cryst., 30 (1997) 565. DOI: $10.1107 / \mathrm{S} 0021889897003117$

[39] I. Moustakali-Mavridis, E. Hadjoudis, A. Mavridis, Structure of thermochromic Schiff bases. II. Structures of $\mathrm{N}$-salicylidene-3-aminopyridine and N-(5-methoxysalicylidene)-3-aminopyridine, Acta Cryst., B36 (1980) 11261130. DOI: $10.1107 /$ S0567740880005432

[40] Ç. Albayrak, G. Kaştaş, M. Odabaşoğlu, R. Frank, The prototropic tautomerism and substituent effect through strong electron withdrawing group in (E)-5-(diethylamino)-2-[(3-nitrophenylimino)methyl]phenol, Spectrochimica Acta Part A, 114 (2013) 205-213. DOI: 10.1016/j.saa.2013.05.044

[41] D. K. Dey, S. P. Dey, A. Elmalı, Y. Elerman, Molecular structure and conformation of N-2-[3'-(methoxysalicylideneimino)benzyl]-3"-methoxysalicylideneimine, J. Mol. Struct., 562 (2001) 177-184. DOI: $10.1016 / \mathrm{S} 0022-2860(00) 00970-4$ 
[42] J. Kruszewski, T. M. Krygowski, Definition of Aromaticity Basing on the Harmonic Oscillator Model, Tetrahedron Lett., 13 (1972) 3839-3842. DOI: $10.1016 / \mathrm{S} 0040-4039(01) 94175-9$

[43] T. M. Krygowski, M. K. Cyrański, Structural Aspects of Aromaticity, Chem. Rev., 101 (2001) 1385-1419. DOI: $10.1021 / \mathrm{cr} 990326 \mathrm{u}$

[44] M. Yıldız, Z. Kılıç, T. Hökelek, Intramolecular hydrogen bonding and tautomerism in Schiff bases. Part 1. Structure of 1,8-di[N-2-oxyphenyl-salicylidene]-3,6-dioxaoctane, J. Mol. Struct., 441 (1998) 1-10. DOI: $10.1016 / \mathrm{S} 0022-2860(97) 00291-3$

[45] A. Filarowski, A. Koll, T. Glowiak, Structure and hydrogen bonding in ortho-hydroxy ketimines, J. Mol. Struct., 644 (2003) 187-195. DOI: $10.1016 /$ S0022-2860(02)00489-1

[46] M. Odabaşoğlu, Ç. Albayrak, R. Özkanca, F.Z. Aykan, P. Lonecke, Some polyhydroxy azo-azomethine derivatives of salicylaldehyde: Synthesis, characterization, spectroscopic, molecular structure and antimicrobial activity studies, J. Mol. Struct., 840 (2007) 71-89. DOI: 10.1016/j.molstruc.2006.11.025

[47] R. Dobosz, A. Skotnicka, Z. Rozwadowski, T. Dziembowska, Stability of N-(ortho-hydroxynaphthylmethylene)methylamines and their tautomers, J. Mol. Struct., 979 (2010) 194-199. DOI: 10.1016/j.molstruc.2010.06.024

[48] K. Ogawa, J. Harada, Aggregation controlled proton tautomerization in salicylideneanilines, J. Mol. Struct., 647 (2003) 211-216. DOI: $10.1016 / \mathrm{S} 0022-2860(02) 00526-4$

[49] S. I. Gorelsky, SWizard program, Revision 4.5. http://www.sg.chem.net/, University of Ottawa, Ottawa, Canada, 2010.

[50] H. Nazır, M. Yıldız, H. Yılmaz, M. N. Tahir, D. Ülkü, Intramolecular hydrogen bonding and tautomerism in Schiff bases, J. Mol. Struct., 524 (2000) 241-250. DOI: $10.1016 / \mathrm{S} 0022-2860(00) 00393-8$
[51] R. M. Silverstein, F. X. Webster, D. J. Kiemle, Spectrometric Identification of Organic Compounds, $7^{\text {th }}$ ed. John Wiley \& Sons, New York, 2005. DOI: 10.1021/ed039p546

[52] B. Koşar, Ç. Albayrak, C. C. Ersanlı, M. Odabaşoğlu, O. Büyükgüngör, Molecular structure, spectroscopic investigations, second-order nonlinear optical properties and intramolecular proton transfer of (E)-5-(diethylamino)2-[(4-propylphenylimino)methyl]phenol: A combined experimental and theoretical study, Spectrochimica Acta Part A, 93 (2012) 1-9. DOI: 10.1016/j.saa.2012.03.004

[53] D. Sajan, J. Hubert, V. S. Jayakumar, J. Zaleski, Structural and electronic contributions to hyperpolarizability in methyl p-hydroxy benzoate, J. Mol. Struct., 785 (2006) 43-53. DOI: 10.1016/j.molstruc.2005.09.041

[54] C. E. Powel, M. G. Humphrey, Nonlinear optical properties of transition metal acetylides and their derivatives, Coord. Chem. Rev., 248 (2004) 725-756. DOI: $10.1016 / j . c c r .2004 .03 .009$

[55] K. S. Thanthiriwatte, K. M. Nalin de Silva, Non-linear optical properties of novel fluorenyl derivatives-ab initio quantum chemical calculations, J. Mol. Struct., Theochem 617 (2002) 169-175.

DOI: $10.1016 / \mathrm{S} 0166-1280(02) 00419-0$

[56] L. Fang, G. C. Yang, Y. Q. Qiu, Z. M. Su, Theoretical predication of third-order optical nonlinearities of $\left[\mathrm{Al}_{4} \mathrm{MAI}_{4}\right]^{\mathrm{n}-}(\mathrm{n}=0-2, \mathrm{M}=\mathrm{Ti}, \mathrm{V}$ and $\mathrm{Cr})$ clusters, Theor. Chem. Account., 119 (2008) 329-333. DOI: $10.1007 / \mathrm{s} 00214-007-0388-1$

[57] Y. X. Sun, Q. L. Hao, W. X. Wei, Z. X. Yu, L. D. Lu, X. Wang, Y. S. Wang, Experimental and density functional studies on 4-(3,4-dihydroxybenzylideneamino)antipyrine, and 4-(2,3,4-trihydroxybenzylideneamino)antipyrine, J. Mol. Struct. Theochem., 904 (2009) 74-82. DOI: $10.1016 / j$.theochem.2009.02.036 